Relations industrielles

Industrial Relations

\title{
Tashakkori, Abbas and Charles Teddlie, Mixed Methodology: Combining Qualitative and Quantitative Approaches
}

\section{John Kervin}

Volume 55, numéro 3, 2000

URI : https://id.erudit.org/iderudit/051336ar

DOI : https://doi.org/10.7202/051336ar

Aller au sommaire du numéro

Éditeur(s)

Département des relations industrielles de l'Université Laval

ISSN

0034-379X (imprimé)

1703-8138 (numérique)

Découvrir la revue

Citer ce compte rendu

Kervin, J. (2000). Compte rendu de [Tashakkori, Abbas and Charles Teddlie, Mixed Methodology: Combining Qualitative and Quantitative Approaches]. Relations industrielles / Industrial Relations, 55(3), 539-540.

https://doi.org/10.7202/051336ar

Tous droits réservés @ C Département des relations industrielles de l'Université Laval, 2000
Ce document est protégé par la loi sur le droit d'auteur. L’utilisation des services d'Érudit (y compris la reproduction) est assujettie à sa politique d'utilisation que vous pouvez consulter en ligne.

https://apropos.erudit.org/fr/usagers/politique-dutilisation/ 
Given my own interests I found this a fascinating book. It brought me up to date as to recent developments. I found myself, however, asking many questions. Values are important, I agree, but I would have liked some questionnaire data which made comparisons, not only over time but among the three coops studied most intensively and also between them and more typical capitalist firms. What differences in value still remain? Among Mondragon's 150 constituent coops are there some where the old values and behaviours still prevail? I wish I knew more about how governance actually works. To what extent are elections contested? What are the election issues? What role does KT (the quasi-union) play? I would have appreciated a few case studies as to how decisions are actually made. As Cheney's liberal quotations illustrate, clearly there are thoughtful individuals in high places who worry about recent trends. How many members share their concerns?

Cooperativism is a dream I share. What did Mondragon do wrong? With the benefit of hindsight, what might it have done differently? If Mondragon's experience was inevitable, what hope is there for developing democratic work systems anywhere? Cheney ends his book with a lengthy discussion of how market principles are becoming predominant, both in Mondragon and society generally. But he suggests few answers to the questions just raised. Neither can I.

George Strauss

University of California, Berkeley

\section{Mixed Methodology: Combining Qualitative and Quantitative Approaches by Abbas TASHakKori and Charles Teddlie, Thousand Oaks, Calif.: Sage Publications, 1998, 185 p., ISBN 0-7619-0070-5 (cloth: alk. paper) and ISBN 0-7619-007103 (pbk.: alk. paper).}

The field of Industrial Relations is a field of battle. The wars I refer to are not between unions and management, but among researchers, over research methodologies. Institutional economists battle those with econometric model approaches. In Sociology and Psychology qualitative case studies vie with survey methods and experimental designs.

Because I.R. is an interdisciplinary field, these disputes are expected. We are nurtured and trained in our disciplinary paradigms - to some of us, research IS regression! But because I.R. is also an applied field, these disputes prevent the field from achieving all it could. Why? The reason is simple. In a traditional academic discipline, problem selection and methods for exploring it are dictated by a paradigm (or one of several paradigms in the war zone that is Sociology). In contrast, applied fields involve real-world, immediate problems of concern to policy-makers or organi- zations, and in solving these problems the most useful results and clearest understanding are achieved when the problem itself drives the choice of methodology.

Alas, most of us are content to remain in the safety of our paradigms. We continue to do variations of regression, or case studies, or surveys, or experiments, because of the comfort and convenience of familiarity, and the suspicion that other methodologies simply do not do it right. In particular, those with quantitative skills do quantitative work, and those with qualitative approaches do qualitative projects. The quantitative/qualitative qualms typify the war - the war between the Qs.

To this battlefield I would like to send in a peace-keeper of a book. Tashakkori and Teddlie offer a compelling and coherent argument for employing a broader range of methodologies in our research. They present a reasoned, 
in-depth, and entertaining guide to combining qualitative and quantitative approaches. Their work offers important insights for those of us working in a multi-disciplinary applied field such as Industrial Relations.

No strangers to battle themselves, Tashakkori and Teddlie begin with an informative discussion of the paradigms and politics of research in the (broadly defined) social and behavioural sciences. Beginning in the $50 \mathrm{~s}$, they trace three stages of the "paradigm wars" between "positivists" and "constructivists", and analyze the differences in logic, the role of values, epistemology, ontology, and the nature of causal linkages. They then discuss the benefits of a pragmatic approach, and strongly endorse the view that research questions drive decisions about methodology. To this they add an extensive analysis of a variety of designs, and data-gathering and dataanalysis techniques, and find common ground in the necessity of ruling out alternative explanations. In itself, this part of the book would be an important addition to most research methods courses.

As well as this informed overview of research methods, a significant contribution of the work is Tashakkori and Teddlie's conceptual model - a well- reasoned and logically exhaustive typology of mixed models and mixed methods They further add a guide and instructions for each type of methodology mix, complete with examples of how to benefit (but only where it actually produces benefits!) from mixed methodology approaches to design, sampling, data collection, and data analysis.

Gratefully, the book is indexed (many in the Sage series are not). The authors write clearly, chapters are introduced and summarized, and the authors suggest along the way who might want to skip what.

I must point out that Tashakkori and Teddlie are not zealots, interested in converting us all to the one true way. At heart, and throughout the book, they are pragmatists whose main concern is to get the research done effectively and validly. If mixed methods do not work better at some stage of the research, don't use them. The benefit for all of us is their patient demonstration, with instruction and examples, that mixed methodology often does work better. Industrial relations will be the better for it.

\section{JoHN KERVIN University of Toronto}

\section{Converging Divergences: Worldwide Changes in Employment Systems}

by Harry C. Katz and Owen Darbishire, Ithaca, N.Y.: ILR Press/Cornell University Press, 2000, 321 p., ISBN: 0-8014-3674-5.

There has been something of a renaissance in comparative industrial relations scholarship. Converging Divergences is the latest in a long line of books which attempts to map global changes in industrial relations. The basic argument of Converging Divergences can be summarized as follows. The authors argue that there are a common set of changes taking place in employment relations in developed economies (like decentralization of bargaining and individualization of relations between employers and employees). They attribute particular importance to a shared increase in the diversity of employment patterns within countries which otherwise differ along a number of dimensions (the U.S., the U.K., Australia, Germany, Sweden, Japan, and Italy). They call this "convergence on divergence'. They claim that this convergent divergence is characterized by the spread of four employment relations patterns - a low wage pattern, an HRM pattern, a Japanese oriented model and 